\title{
EFFECT OF NITROGENOUS FERTILIZERS FACTORY (TALKHA FERTILIZERS FACTORY) ON NITRATE STATUS IN THE AGRICULTURAL ENVIRONMENT.
}

Tantawy, Manal F. ${ }^{1}$; S. A. Abou Elnaga ${ }^{2}$; E. A. Abou Hussien ${ }^{2}$ and M. S. Abou Alfotoh ${ }^{1}$

1- Soil, Water and Environment, Inst, Res. Agric. Rrs. Center, Giza, Egypt

2- Soil Sci.Dep. Fac. of Agric Minoufia Univ. Egypt

\begin{abstract}
This research work was carried out to evaluate nitrogenous fertilizers factory (Talkha fertilizers factory) as a source of nitrate pollution and its content in the soil, irrigation and drainage water and cultivated plants in its Talkha area, Dakahlia Governorate, Egypt. Soil samples were taken at soil depths of 0-15, 15-30, 30-60 and $60-90 \mathrm{~cm}$ at five distances of the factory .i.e. at before $500 \mathrm{~m}$ of the factory (as control), 0, 500, 1000 and $1500 \mathrm{~m}$ after them. These soil samples were analyzed for some physical and chemical properties and also for its content of different $\mathrm{N}$-forms .i.e. total $-\mathrm{N}, \mathrm{NH}_{4}-\mathrm{N}, \mathrm{NO}_{3}-\mathrm{N}, \mathrm{NO}_{2}-\mathrm{N}$ and organic- $\mathrm{N}(\mathrm{O}-\mathrm{N})$. At the soil sampling sites, samples of both irrigation and drainage water were taken and analyzed for their $\mathrm{pH}$, $\mathrm{EC}$ and the content of both $\mathrm{NH}_{4}-\mathrm{N}$ and $\mathrm{NO}_{3}-\mathrm{N}$. At the same sites, samples of cultivated plants were taken and analyzed for the content of total $-\mathrm{N}, \mathrm{NH}_{4}-\mathrm{N}$ and $\mathrm{NO}_{3}-$ $\mathrm{N}$. After that, the relationships between some soil properties and its content of different $\mathrm{N}$ - forms were calculated. From theses relations and predication equations the predict soil content of $\mathrm{NO}_{3}-\mathrm{N}$ was calculated.

The obtained data show that, the soil content $(\mathrm{mg} / \mathrm{kg})$ of different $\mathrm{N}$ forms was decreased with the increase of soil depth, except $\mathrm{NO}_{3}-\mathrm{N}$ was increased with the soil depth up to $60 \mathrm{~cm}$. Also, the content of these forms was decreased with the distance increase of the factory. The relationships between soil properties and the content of different $\mathrm{N}$ - forms varied depending on the studied soil property and $\mathrm{N}$-forms. Generally, the prediction values of $\mathrm{NO}_{3}-\mathrm{N}$ were higher than those of determined $\mathrm{NO}_{3}-$ $\mathrm{N}$. Also both irrigation and drainage water and plant samples content of both $\mathrm{NH}_{4}-\mathrm{N}$ and $\mathrm{NO}_{3}-\mathrm{N}$ was decreased with the distance of the factory increase.

Keywords: Pollution, Nitrate, Nitrogenous fertilizers, Prediction equations and Soil properties.
\end{abstract}

\section{INTRODUCTION}

Berrow and Reaves (1984) reported that soils have became polluted if contents of a metal exceed the upper end of an accepted normal range. They also added that the continuous accumulation of harmfull metals and their persistence in soil makes soil pollution a far more serious matter than either air or water pollution. Al-Othman et al. (2011) pointed out that heavy metals accumulation is one of the most serious environmental concerns of the present day, not only because many of these metals are toxic to the crops themselves, but also because of their potential harm to animals and humans. Found metals are non-biodegradable and are considered major environmental pollutants resulting in cyto toxic, mutagenic and carcinogenic effects in animals. WHO (2004) found that biogeochemical processes are 
known to modify nitrate concentrations such the different forms of nitrogen $\left(\mathrm{NO}_{2}{ }^{-}, \mathrm{NH}_{4}^{+}, \mathrm{NH}_{3}\right)$ can potentially be transformed into nitrate. The objective of Garizabal et al. (2012) investigation was to analyze the evolution of nitrate contamination in relation to agronomic and management changes within a traditionally irrigated soil. That specifically, the impact of changes in irrigation allowance assignment, changes in irrigation method from rotation to ondemand flood irrigation, and creation of water consumption accounts were analyzed. That to this end, nitrogen monitoring and annual balances were carried out in a small irrigated hydrological basin (95 ha) located in Northeastern Spain throughout the years of 2001 and 2005-2008. That the evolution of the nitrate contamination index was also analyzed, which relates the mass of nitrates exported to the fertilization necessities of a specific irrigated area. Found that the results demonstrated that although changes in crop pattern caused a $33 \%$ reduction in the nitrogen required through fertilization, the fertilization rates applied are still double the necessities. Yang et al. (2006) found accumulation and distribution of $\mathrm{NO}_{3}-\mathrm{N}$ in soil was significantly affected by annual fertilizations. Mineral fertilizers (NP and NPK) led to $\mathrm{NO}_{3}-\mathrm{N}$ accumulation in most subsoil layers, with major impact in the 20-140 cm depth. Found the combination of mineral fertilizers and farmyard manure (MNP and MNPK) reduced soil $\mathrm{NO}_{3}-\mathrm{N}$ accumulation in comparison to mineral fertilizers. Sapek (2005) pointed that agriculture is probably the largest contributor of nitrogen pollution to ground water, as nitrate originates both from soil $\mathrm{N}$-mineralization and nitrification and from excessive use of $\mathrm{N}$ fertilizers and manure on arable crops in order to increase yields and product quality. Cemek et al. (2007) found that nitrate and nitrite levels in our natural water supplies are important indicators of water quality. The increasing levels of nitrate and nitrite concentrations are becoming an important problem for public health. Nitrates are of great toxicological concern as they are involved in the origin of nitrites and nitrosamines and the development of metahaemoglobinaemia in infants. It is well known that high level nitrite is toxic to alga. Laboratory studies carried out by Katerji et al. (2001) have shown that soil salinity reduces nitrogen content and salinity affecting the nitrification. The salinity effect on bacterial activity with respect to nitrogen fixation is one of the hypo theses for explaining its salt sensitivity. Bertrand et al. (2007) found that positive correlations between the amounts of $\mathrm{NO}_{3}{ }^{-}$ immobilized and soil pH changes by the release of hydroxyl ions by the soil microbial biomass which served to balance the charge in response to anion uptake $\left(\mathrm{NO}_{3}{ }^{-}\right)$. Barrett and Burke (2000) observed that soils with higher organic matter content and wide soil $\mathrm{C} / \mathrm{N}$ ratios may immobilize more $\mathrm{N}$ than soils with less soil OM because of a limitation of reduced $C$ substrate to microbial metabolism. Organic substrates with wide $\mathrm{C} / \mathrm{N}$ ratios often support microbial communities that are $\mathrm{N}$ limited and generally exhibit higher rates of $\mathrm{N}$ immobilization presumably because microbes require additional mineral $\mathrm{N}$ to metabolize material with high $\mathrm{C}$ content relative to $\mathrm{N}$. In a field experiment, Eltilib et al. (2005) found that $\mathrm{CaCO}_{3}$ caused a substantial reduction in nitrogen availability and, hence, in maize yield in Al-Marj soil. It was not clear from that experiment whether the negative effect of $\mathrm{CaCO}_{3}$ was due to poor 
nitrogen transformation or due to leaching. Gami et al. (2009) reported that positive relationships between total $\mathrm{N}$ and silt + clay content were found for both forested and cultivated soils for all of the soil depths $0-15 \mathrm{~cm}$ and $15-30$ $\mathrm{cm}$. El-Melegy (2007) reported that the relationships between the soil profiles content of available- $\mathrm{N}$ and the soil content of clay and $\mathrm{OM}$ and values of CEC were positive and its were negative with soil $\mathrm{pH}$. Also, the trend of relative decrease values of total available- $\mathrm{N}$ with soil depth was unclear. Jagessar and Alleyne (2011) showed that soil bacteria derive their energy by oxidizing ammonia to nitrite $\left(\mathrm{NO}_{2}{ }^{-}\right)$and ultimately to nitrate, $\mathrm{NO}_{3}{ }^{-}$. These bacteria are abundant and active that all ammonia reaching the soil is oxidized to nitrate. This process is known as nitrification. Plants and many bacteria take up and readily reduce nitrate and nitrite through the action of nitrate and nitrite reductases. The ammonia that is formed is incorporated into amino acids by plants.

This work was carried out to study the effect of mineral nitrogen fertilizers on the soil content of different $\mathrm{N}$ - form especially that of nitrate form and found the relationships between these forms and soil physical and chemical properties. Also, irrigation and drainage water and plants content of the determined $\mathrm{N}$-forms were determined.

\section{MATERIALS AND METHODS}

\section{Soil Locations and Its Sampling}

The studied area in this investigation is represent the alluvial soil of Meet Anter Village around at Talkha fertilizer factory, Talkha, Dakahlia Governorate (Fig 1). The selected area was carried out based their production polluted by nitrate. Soil samples were collected at different distances of factory (nitrate source) .i.e. $-500 \mathrm{~m}$ before factory (which represent the control), 0, 500, 1000 and $1500 \mathrm{~m}$ (Fig 2). At each distance, the sampling process was conducted at four soil depth i.e. 0 - 15, $15-30$, $30-60$ and $60-90 \mathrm{~cm}$. Each soil sample was air-dried separately, ground, good mixed, sived through a $2 \mathrm{~mm}$ sieve and kept into plastic bottles. Some physical and chemical properties for these samples were determined according to the methods described by Page et al. (1982), Cottenie et al. (1982) and Kim (1996). The obtained data were listed in Tables (1 to 3).

\section{Irrigation and Drainage Water Samples}

At each distance of premonitioned soil sampling process, samples of both irrigation and drainage water were taken. Irrigation water resources in the studied area was Nile River water. On the other hand the drainage water samples were taken from the collector hole of tile drains. The samples of both irrigation and drainage water were taken according to APHA (1995) method, and analyzed for its $\mathrm{pH}$ and $\mathrm{EC}$ according to the methods described by Cottenie et al. (1982).

Total nitrogen was determined in all soil samples digestion by mixture of conc $\mathrm{HClO}_{4}$ and $\mathrm{H}_{2} \mathrm{SO}_{4}$ (1:3 ratio) using method of Kjeldahl as described by 
Page et al. (1982). Nitrate and ammonium - nitrogen were extracted and determined by Kjeldahl distillation according to the method described by Page et al. (1982). Also, nitrite content was determined using as spectrophotometer described by Bremner and Keeney (1966). Finally organic nitrogen $(\mathrm{ON})$ : was calculated by subtracting Total nitrogen (T-N) - sumation $\left(\mathrm{NO}_{3}-\mathrm{N}+\mathrm{NH}_{4}-\mathrm{N}+\mathrm{NO}_{2}-\mathrm{N}\right)$. Nitrate and ammonium were determined by Kjeldahl distillation as described by Cottenie et al. (1982). Statical Analysis was calculated by mtb12 Program.

\section{Plant Samples and Its Analysis}

At each distance of soil sampling, samples, of grown plant (Corn, Rice, Clover and Vridity) was taken and divided into shoots and roots, air-dried at $70{ }^{\circ} \mathrm{C}$, ground and kept into plastic bags. 0.2 gram of the oven dried plant sample was digested with $5 \mathrm{ml}$ of concentrated percholoric acids $\left(\mathrm{HClO}_{4}\right)+$ sulfuric acid $\left(\mathrm{H}_{2} \mathrm{SO}_{4}\right)$ at mixed ratio mixture of $1: 3$ on a hot-plate until the digest become clear and uncolored. The digest was diluted to $100 \mathrm{ml}$ with distilled water according to Chapman and Pratt (1961) and determined the plant content of total nitrogen. The $\mathrm{NH}_{4}-\mathrm{N}$ and $\mathrm{NO}_{3}-\mathrm{N}$ were determined. Nitrogen content in plant samples digestion was determined as a percentage (Total-N \%) using conventional method of Kjeldahl as described by Page et al. (1982). Determination of nitrate and ammonia were carried out by Kjeldahl distillation (Cottenie et al., 1982).

\section{RESULTS AND DISCUSSION}

\section{The Soil Content Of Different Nitrogen Forms Total nitrogen (T-N).}

The recorded data in Table (4) show a wide variations in the soil content $(\mathrm{mg} / \mathrm{kg})$ of T-N in the studied area. For example, this content ranged from $515 \mathrm{mg} / \mathrm{kg}$ in $60-90 \mathrm{~cm}$ of profile 1 to $9300 \mathrm{mg} / \mathrm{kg}$ in the surface $0-15 \mathrm{~cm}$ layer of profile 2. In addition, this content was decreased with dis0tance increase of the factory as well as with the increase of soil depth (except the control profile). Generally, the soil in the studied area may be characterized by high content of T-N. This trend show fertilizers factory resulted in an increase of soil content of $\mathrm{T}-\mathrm{N}$, where the found increase resulted from the outline products of this factory. Such this effect was reported by WHO (2004); Mahvi et al. (2005); Angelopoulos et al. (2009); Nettleton and Peterson (2010); Hongmei et al. (2011) and Garizabal et al. (2012). 
J. Soil Sci. and Aqric. Enq., Mansoura Univ., Vol. 5 (5), Mav, 2014
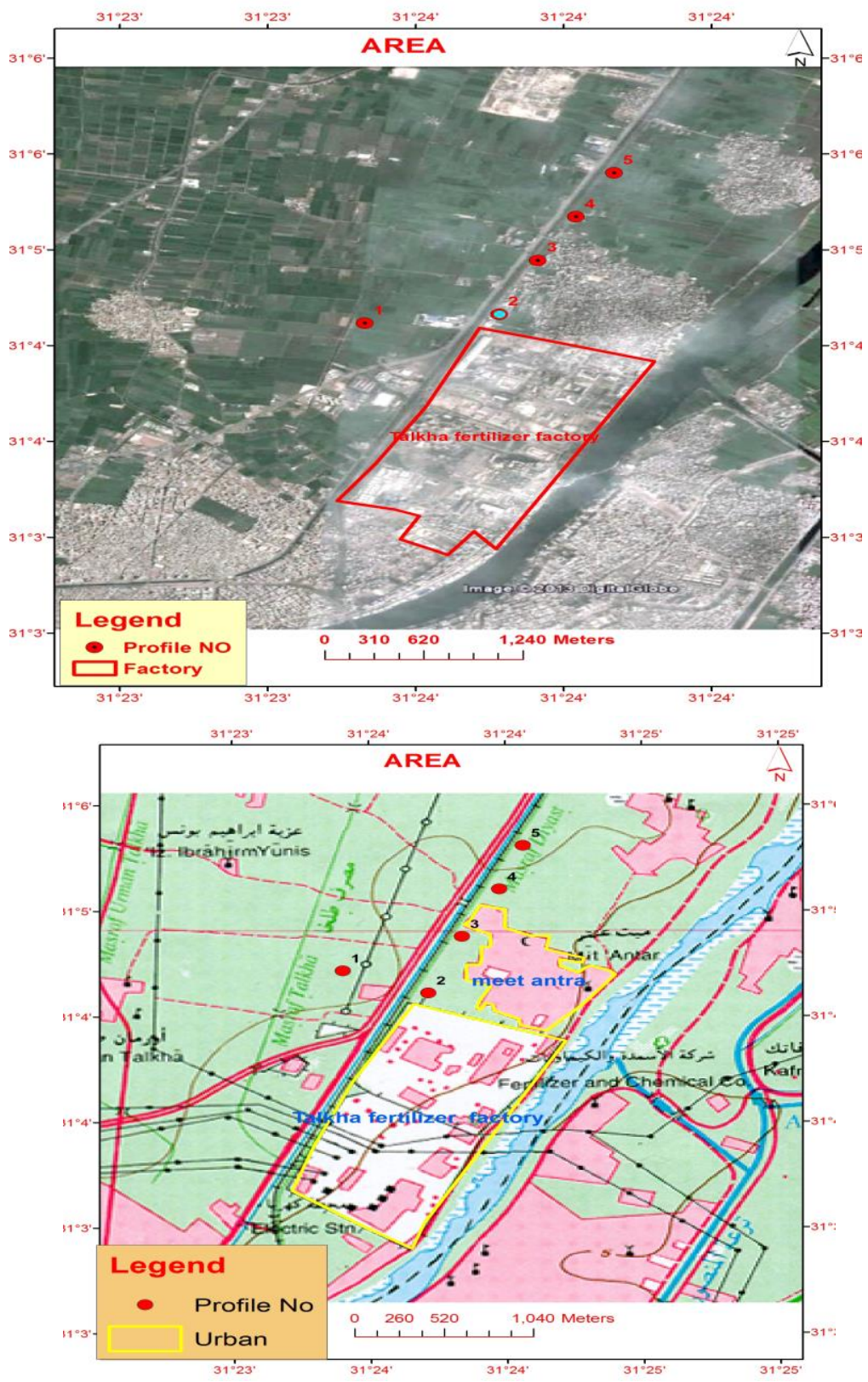

Figs (1 and 2): Map location and sites of the studied soil profiles of Talkha area Dakahlia Governorate, Egypt. 
Table (1). Particle size distribution of (\%) texture class, and saturation percent (SP) of the selected samples taken from different soil profiles of Talkha, Dakahlia Governorate at different distances from Talkha Fertilizer factory.

\begin{tabular}{|c|c|c|c|c|c|c|c|c|}
\hline $\begin{array}{c}\text { Profile } \\
\text { No }\end{array}$ & $\begin{array}{l}\text { Distance } \\
\text { from } \\
\text { factory (M) }\end{array}$ & $\begin{array}{c}\text { Soil } \\
\text { depth } \\
(\mathrm{cm})\end{array}$ & $\begin{array}{l}\text { Coarse } \\
\text { sand } \\
(\%)\end{array}$ & $\begin{array}{l}\text { Fine } \\
\text { sand } \\
(\%)\end{array}$ & $\begin{array}{l}\text { Silt } \\
(\%)\end{array}$ & Clay (\%) & $\begin{array}{l}\text { Texture } \\
\text { class }\end{array}$ & $\begin{array}{l}\text { SP } \\
\%\end{array}$ \\
\hline \multirow{4}{*}{1} & \multirow{4}{*}{-500} & $0-15$ & 2.30 & 13.98 & 35.02 & 48.70 & Clay & 83.13 \\
\hline & & $15-30$ & 2.15 & 20.17 & 32.45 & 45.23 & Clay & 82.25 \\
\hline & & $30-60$ & 2.12 & 21.64 & 33.89 & 42.35 & Clay & 74.38 \\
\hline & & $60-90$ & 2.00 & 21.68 & 30.45 & 45.87 & Clay & 73.50 \\
\hline \multirow{4}{*}{2} & \multirow{4}{*}{000} & $0-15$ & 2.02 & 16.65 & 34.49 & 46.84 & Clay & 70.00 \\
\hline & & $15-30$ & 1.60 & 19.98 & 30.78 & 47.64 & Clay & 78.75 \\
\hline & & $30-60$ & 1.21 & 25.88 & 30.45 & 42.46 & Clay & 78.75 \\
\hline & & $60-90$ & 1.03 & 28.04 & 31.78 & 39.15 & Clay - Ioam & 74.38 \\
\hline \multirow{4}{*}{3} & \multirow{4}{*}{500} & $0-15$ & 1.53 & 19.12 & 35.78 & 43.57 & Clay & 74.38 \\
\hline & & $15-30$ & 1.25 & 23.12 & 30.12 & 45.51 & Clay & 76.13 \\
\hline & & $30-60$ & 1.01 & 23.85 & 29.82 & 45.32 & Clay & 65.63 \\
\hline & & $60-90$ & 0.98 & 24.67 & 25.78 & 48.57 & Clay & 70.00 \\
\hline \multirow{4}{*}{4} & \multirow{4}{*}{1000} & $0-15$ & 1.75 & 19.84 & 35.74 & 42.67 & Clay & 70.00 \\
\hline & & $15-30$ & 1.56 & 24.58 & 35.45 & 38.41 & Clay - Ioam & 70.00 \\
\hline & & $30-60$ & 1.50 & 25.00 & 30.88 & 42.62 & Clay & 74.38 \\
\hline & & $60-90$ & 1.34 & 26.09 & 30.12 & 42.45 & Clay & 78.75 \\
\hline \multirow{4}{*}{5} & \multirow{4}{*}{1500} & $0-15$ & 1.75 & 18.18 & 33.15 & 46.92 & Clay & 71.84 \\
\hline & & $15-30$ & 1.60 & 21.25 & 32.50 & 44.65 & Clay & 70.44 \\
\hline & & $30-60$ & 1.50 & 23.50 & 31.17 & 43.83 & Clay & 71.14 \\
\hline & & $60-90$ & 1.28 & 24.12 & 30.10 & 44.50 & Clay & 70.44 \\
\hline
\end{tabular}

Table (2). Soil EC ( $\left.\mathrm{dSm}^{-1}\right)$ and the content (meq/l) of soluble cations and anions in the selected soil profiles located around Talkha fertilizer factory of Talkha, Dakahlia Governorate.

\begin{tabular}{|c|c|c|c|c|c|c|c|c|c|c|c|}
\hline \multirow{2}{*}{$\begin{array}{c}\text { Profile } \\
\text { No }\end{array}$} & \multirow{2}{*}{$\begin{array}{l}\text { Distance } \\
\text { from } \\
\text { factory } \\
\text { (M) }\end{array}$} & \multirow{2}{*}{$\begin{array}{c}\text { Soil } \\
\text { depth } \\
\text { (cm) }\end{array}$} & \multirow[b]{2}{*}{$\left(\mathrm{d} \mathrm{EC}^{-1}\right)$} & \multicolumn{4}{|c|}{ Soluble cations (meg/l) } & \multicolumn{4}{|c|}{ Soluble anions (meq/I) } \\
\hline & & & & $\mathrm{Na}^{+}$ & $\mathrm{K}^{+}$ & $\mathrm{Ca}^{+2}$ & $\mathrm{Mg}^{+2}$ & $\mathrm{Cl}^{-1}$ & $\mathrm{CO}_{3}$ & $\mathrm{HCO}_{3}{ }^{-1}$ & $\mathrm{SO}_{4}^{-2}$ \\
\hline \multirow{5}{*}{1} & \multirow{5}{*}{-500} & $0-15$ & 2.05 & 13.15 & 0.20 & 3.65 & 3.50 & 15.13 & 000 & 2.53 & 2.84 \\
\hline & & $15-30$ & 1.60 & 9.25 & 0.18 & 3.11 & 3.46 & 10.45 & 000 & 2.35 & 3.20 \\
\hline & & $30-60$ & 1.40 & 8.35 & 0.14 & 2.90 & 2.61 & 9.50 & 000 & 2.01 & 2.49 \\
\hline & & $60-90$ & 1.22 & 7.35 & 0.13 & 2.50 & 2.22 & 8.15 & 000 & 1.73 & 2.32 \\
\hline & & Mean & 1.56 & 9.53 & 0.16 & 3.04 & 2.95 & 10.81 & 000 & 2.16 & 2.71 \\
\hline \multirow{5}{*}{2} & \multirow{5}{*}{000} & $0-15$ & 4.15 & 30.88 & 1.33 & 6.15 & 3.14 & 25.30 & 000 & 3.30 & 12.90 \\
\hline & & $15-30$ & 3.80 & 21.09 & 1.27 & 6.15 & 9.49 & 37.14 & 000 & 2.75 & 1.89 \\
\hline & & $30-60$ & 3.50 & 20.78 & 1.22 & 4.92 & 8.08 & 21.84 & 000 & 2.75 & 10.41 \\
\hline & & $60-90$ & 2.02 & 11.13 & 1.25 & 3.69 & 4.13 & 13.68 & 000 & 2.47 & 4.05 \\
\hline & & Mean & 3.67 & 20.97 & 1.27 & 5.23 & 6.21 & 24.49 & 000 & 2.82 & 7.31 \\
\hline \multirow{5}{*}{3} & \multirow{5}{*}{500} & $0-15$ & 3.19 & 20.10 & 1.27 & 5.56 & 4.97 & 24.84 & 000 & 3.03 & 4.03 \\
\hline & & $15-30$ & 2.91 & 19.55 & 1.19 & 4.10 & 4.26 & 22.70 & 000 & 2.70 & 3.70 \\
\hline & & $30-60$ & 2.62 & 18.11 & 1.27 & 3.69 & 3.13 & 21.05 & 000 & 2.65 & 2.50 \\
\hline & & $60-90$ & 2.52 & 16.68 & 1.13 & 3.28 & 4.11 & 18.02 & 000 & 2.55 & 4.63 \\
\hline & & Mean & 2.81 & 18.61 & 1.22 & 4.16 & 4.12 & 21.66 & 000 & 2.73 & 3.72 \\
\hline \multirow{5}{*}{4} & \multirow{5}{*}{1000} & $0-15$ & 3.10 & 22.86 & 0.25 & 4.51 & 3.38 & 25.96 & 000 & 2.75 & 2.29 \\
\hline & & $15-30$ & 2.50 & 16.90 & 0.22 & 4.10 & 3.78 & 17.32 & 000 & 2.75 & 4.93 \\
\hline & & $30-60$ & 2.25 & 14.11 & 0.20 & 3.69 & 4.50 & 15.61 & 000 & 2.48 & 4.41 \\
\hline & & $60-90$ & 1.90 & 13.50 & 0.17 & 3.69 & 1.64 & 15.80 & 000 & 1.93 & 7.27 \\
\hline & & Mean & 2.44 & 16.84 & 0.21 & 3.99 & 3.33 & 18.67 & 000 & 2.48 & 3.23 \\
\hline \multirow{5}{*}{5} & \multirow{5}{*}{1500} & $0-15$ & 2.38 & 15.34 & 0.27 & 4.92 & 3.27 & 13.88 & 000 & 2.75 & 7.17 \\
\hline & & $15-30$ & 1.72 & 10.87 & 0.27 & 3.44 & 2.62 & 12.88 & 000 & 2.50 & 1.82 \\
\hline & & $30-60$ & 1.70 & 10.44 & 0.20 & 3.28 & 3.08 & 11.64 & 000 & 2.33 & 3.03 \\
\hline & & $60-90$ & 1.42 & 8.20 & 0.20 & 2.87 & 2.93 & 10.81 & 000 & 1.82 & 7.57 \\
\hline & & Mean & 1.81 & 11.21 & 0.24 & 3.63 & 2.98 & 12.30 & 000 & 2.35 & 3.39 \\
\hline
\end{tabular}


Table (3): Some chemicals properties of the studied soil samples taken from soil profiles around Talkha fertilizer factory at Talkha, Dakahlia Governorate.

\begin{tabular}{|c|c|c|c|c|c|c|c|c|}
\hline \begin{tabular}{|c|} 
Profile \\
No. \\
Profile \\
No \\
\end{tabular} & \begin{tabular}{|c}
$\begin{array}{c}\text { Distance } \\
\text { from } \\
\text { factory } \\
\text { (M) }\end{array}$ \\
\end{tabular} & $\begin{array}{l}\text { Soil } \\
\text { depth } \\
(\mathrm{cm})\end{array}$ & $\begin{array}{l}\text { pH In (1:2.5) } \\
\text { (soil : water) } \\
\text { suspension }\end{array}$ & $\underset{(g / 100 g)}{O M}$ & $\begin{array}{c}\mathrm{CaCO}_{3} \\
(\mathrm{~g} / 100 \mathrm{~g})\end{array}$ & $\begin{array}{c}\text { CEC } \\
\text { (meq } / 100 \mathrm{~g})\end{array}$ & $\begin{array}{c}\text { Available } \\
\mathbf{P} \\
(\mathbf{m g} / \mathbf{k g})\end{array}$ & $\begin{array}{c}\text { Available } \\
\mathrm{K} \\
(\mathrm{mg} / \mathrm{kg})\end{array}$ \\
\hline \multirow{5}{*}{1} & \multirow{5}{*}{-500} & $0-15$ & 8.61 & 1.90 & 3.80 & 46.15 & 8.15 & 1815.60 \\
\hline & & $15-30$ & 8.65 & 1.15 & 2.75 & 45.55 & 6.72 & 1612.00 \\
\hline & & $30-60$ & 8.80 & 0.50 & 2.63 & 44.10 & 6.15 & 1416.40 \\
\hline & & $60-90$ & 8.85 & 0.35 & 1.40 & 43.50 & 5.10 & 1213.00 \\
\hline & & Mean & 8.73 & & & 44.83 & 6.53 & 1512.60 \\
\hline \multirow{5}{*}{2} & \multirow{5}{*}{000} & $0-15$ & 8.45 & 2.20 & 5.47 & 49.15 & 12.20 & 2418.00 \\
\hline & & $15-30$ & 8.50 & 1.60 & 4.61 & 42.68 & 11.30 & 2011.00 \\
\hline & & $30-60$ & 8.55 & 0.65 & 2.61 & 43.72 & 11.22 & 1815.60 \\
\hline & & $60-90$ & 8.70 & 0.43 & 1.29 & 41.14 & 9.98 & 1612.00 \\
\hline & & Mean & 8.59 & & & 44.76 & 11.18 & 1862.80 \\
\hline \multirow{5}{*}{3} & \multirow{5}{*}{500} & $0-15$ & 8.50 & 2.15 & 3.02 & 53.06 & 11.31 & 2011.20 \\
\hline & & $15-30$ & 8.55 & 1.60 & 2.54 & 51.11 & 11.01 & 2011.20 \\
\hline & & $30-60$ & 8.55 & 0.60 & 1.68 & 50.81 & 11.00 & 1416.40 \\
\hline & & $60-90$ & 8.55 & 0.40 & 1.38 & 42.78 & 9.69 & 1416.40 \\
\hline & & Mean & 8.61 & & & 49.62 & 10.72 & 1661.40 \\
\hline \multirow{5}{*}{4} & \multirow{5}{*}{100} & $0-15$ & 8.55 & 2.04 & 5.17 & 51.06 & 11.03 & 2011.20 \\
\hline & & $15-30$ & 8.60 & 1.00 & 3.07 & 50.69 & 10.96 & 2011.20 \\
\hline & & $30-60$ & 8.60 & 0.53 & 2.20 & 48.43 & 10.57 & 1408.60 \\
\hline & & $60-90$ & 8.65 & 0.40 & 4.31 & 46.17 & 9.00 & 1001.60 \\
\hline & & Mean & 8.60 & & & 48.42 & 10.39 & 1659.40 \\
\hline \multirow{5}{*}{5} & \multirow{5}{*}{1500} & $0-15$ & 8.59 & 1.90 & 4.74 & 44.16 & 9.46 & 2001.00 \\
\hline & & $15-30$ & 8.64 & 1.20 & 2.16 & 45.01 & 9.98 & 1803.60 \\
\hline & & $30-60$ & 8.72 & 0.50 & 1.26 & 44.16 & 8.99 & 1418.00 \\
\hline & & $60-90$ & 8.75 & 0.36 & 1.43 & 40.14 & 6.66 & 1206.60 \\
\hline & & Mean & 8.68 & & & 44.21 & 8.77 & 1607.20 \\
\hline
\end{tabular}

Amonium nitrogen $\left(\mathrm{NH}_{4}-\mathrm{N}\right)$.

The listed values of soil samples under study content $(\mathrm{mg} / \mathrm{kg})$ of available $\mathrm{NH}_{4}-\mathrm{N}$ and its a percent of total $-\mathrm{N}$ were shown in Table (4) that reveals that in all soil profiles, the content of $\mathrm{NH}_{4}-\mathrm{N}$ was decreased with the increase of soil depth. This trend was related positively with the soil content of both fine fraction and organic matter. Also, in the studied area this content was decreased with the distance increase from the factory, except the profile number1 located before the factory. So, the highest content of $\mathrm{NH}_{4}-\mathrm{N}$ was found in the surface layer $(0-15 \mathrm{~cm})$ of profile 2 . The studied soil samples of Talkha area are characterized by a high content of $\mathrm{NH}_{4}-\mathrm{N}$. This finding show the clear effect of fertilizer factory on the soil content of $\mathrm{NH}_{4}-\mathrm{N}$. For example, this content increase from $135.00 \mathrm{mg} / \mathrm{kg}$ in the deeper layer of profile 1 to $546.00 \mathrm{mg} / \mathrm{kg}$ in the surface $0-15 \mathrm{~cm}$ of profile 2 .

Regarding the soil samples under study, content of $\mathrm{NH}_{4}-\mathrm{N}$ as a percent of T-N, as percented in Table (4) show that $\mathrm{NH}_{4}-\mathrm{N}$ represent the third fraction of $\mathrm{T}-\mathrm{N}$ in the soil samples of Talkha area. The highest $\mathrm{NH}_{4}-\mathrm{N}$ as a 
percent of T-N were found in the different layers of profile 1, where the lowest values were found within profile 2.

Nitrate nitrogen $\left(\mathrm{NO}_{3}-\mathrm{N}\right)$.

The recorded data in Table (4) show the effect of outline products of fertilizers factory on soil content of $\mathrm{NO}_{3}-\mathrm{N}$ as $\mathrm{mg} / \mathrm{kg}$ and as a percent of $\mathrm{T}-\mathrm{N}$. These data show, at different distance from the factory, the soil content of $\mathrm{NO}_{3}-\mathrm{N}$ was increased with soil depth up to $30-60 \mathrm{~cm}$ depth and turned to decrease at the more depth. This means that, the high content of $\mathrm{NO}_{3}-\mathrm{N}$ was found at soil depth of $30-60 \mathrm{~cm}$. These findings attributed to $\mathrm{NO}_{3}^{-}$leaching with irrigation water. Also, the soils content of $\mathrm{NO}_{3}-\mathrm{N}$ was decreased with the distance increased from factory, except profile 1. This trend cleared that outline products of the tested industrial activities resulted in a clear increase of the nearest soil content of $\mathrm{NO}_{3}-\mathrm{N}$. So, the mean content of $\mathrm{NO}_{3}-\mathrm{N}$ in profile 1 was $321.25 \mathrm{mg} / \mathrm{kg}$ and was $525.00 \mathrm{mg} / \mathrm{kg}$ in profile 2 .

Table (4): The studied soil samples content $(\mathrm{mg} / \mathrm{kg}$ ) of different $\mathrm{N}$ forms and its percent (\%) of T-N through different layers of soil profiles taken at different distance of Talkha fertilizer factory of Talkha, Dakahlia Governorate.

\begin{tabular}{|c|c|c|c|c|c|c|c|c|c|c|c|}
\hline \multirow[b]{2}{*}{$\begin{array}{c}\text { Profile } \\
\text { No }\end{array}$} & \multirow{2}{*}{$\begin{array}{c}\text { Distance } \\
\text { from } \\
\text { factory } \\
\text { (M) }\end{array}$} & \multirow{2}{*}{$\begin{array}{c}\text { Soil } \\
\text { depth } \\
\text { (cm) }\end{array}$} & \multirow{2}{*}{\begin{tabular}{|l}
${ }^{*} \mathrm{~T}-\mathrm{N}$ \\
$\mathrm{mg} / \mathrm{kg}$
\end{tabular}} & \multicolumn{2}{|c|}{${ }^{*} \mathrm{NH}_{4}-\mathrm{N}$} & \multicolumn{2}{|c|}{${ }^{*} \mathrm{NO}_{3}-\mathrm{N}$} & \multicolumn{2}{|c|}{${ }^{*} \mathrm{NO}_{2}-\mathrm{N}$} & \multicolumn{2}{|c|}{${ }^{\star} \mathrm{O}-\mathrm{N}$} \\
\hline & & & & $\underset{\mathbf{k g}}{\mathbf{m g} /}$ & $\begin{array}{l}\% \text { of } \\
\text { T-N }\end{array}$ & $\begin{array}{c}\mathbf{m g} / \\
\mathbf{k g}\end{array}$ & $\begin{array}{l}\text { \%of } \\
\text { T-N }\end{array}$ & mg & $\begin{array}{l}\% \text { of } \\
\text { T-N }\end{array}$ & $\begin{array}{l}\mathrm{Mg} \\
/ \mathrm{kg}\end{array}$ & $\begin{array}{l}\text { \%of } \\
\text { T-N }\end{array}$ \\
\hline \multirow{5}{*}{1} & \multirow{5}{*}{-500} & $0-15$ & 2030.00 & 370.00 & 18.22 & 285.00 & 14.04 & 1.22 & 0.06 & 1373.78 & 67.67 \\
\hline & & $15-30$ & 1115.00 & 265.00 & 23.77 & 370.00 & 33.18 & 1.10 & 0.09 & 478.90 & 42.95 \\
\hline & & $30-60$ & 790.00 & 175.00 & 22.15 & 385.00 & 48.73 & 0.96 & 0.12 & 229.04 & 28.99 \\
\hline & & $60-90$ & 515.00 & 135.00 & 26.21 & 245.00 & 47.57 & 0.78 & 0.15 & 134.22 & 26.06 \\
\hline & & Mean & 1112.50 & 236.25 & & 321.25 & & 1.02 & & 553.98 & \\
\hline \multirow{5}{*}{2} & \multirow{5}{*}{000} & $0-15$ & 9300.00 & 546.00 & 5.87 & 505.00 & 5.43 & 2.15 & 0.02 & 8246.85 & 88.68 \\
\hline & & $15-30$ & 8600.00 & 473.00 & 5.50 & 595.00 & 6.91 & 2.05 & 0.02 & 7529.95 & 87.56 \\
\hline & & $30-60$ & 5100.00 & 450.00 & 8.82 & 590.00 & 11.56 & 1.60 & 0.02 & 4058.40 & 79.58 \\
\hline & & $60-90$ & 4680.00 & 410.00 & 8.77 & 410.00 & 8.76 & 1.38 & 0.03 & 3858.62 & 82.45 \\
\hline & & Mean & 6920.00 & 469.75 & & 525.00 & & 1.80 & & 5923.46 & \\
\hline \multirow{5}{*}{3} & \multirow{5}{*}{500} & $0-15$ & 8300.00 & 493.00 & 5.94 & 478.00 & 5.76 & 2.15 & 0.03 & 7326.85 & 88.28 \\
\hline & & $15-30$ & 7700.00 & 456.00 & 5.92 & 521.00 & 6.76 & 1.95 & 0.03 & 6721.05 & 87.29 \\
\hline & & $30-60$ & 7600.00 & 425.00 & 5.59 & 552.00 & 7.26 & 1.50 & 0.02 & 6621.50 & 87.13 \\
\hline & & $60-90$ & 3010.00 & 398.00 & 13.22 & 395.00 & 13.12 & 1.20 & 0.03 & 2215.80 & 73.61 \\
\hline & & Mean & 6652.50 & 443.00 & & 486.50 & & 1.70 & & 5721.30 & \\
\hline \multirow{5}{*}{4} & \multirow{5}{*}{1000} & $0-15$ & 3700.00 & 483.00 & 13.05 & 460.00 & 12.43 & 1.90 & 0.05 & 2755.10 & 74.46 \\
\hline & & $15-30$ & 2100.00 & 444.00 & 21.14 & 492.00 & 23.42 & 1.62 & 0.07 & 1162.38 & 55.35 \\
\hline & & $30-60$ & 1300.00 & 392.00 & 30.15 & 520.00 & 40.00 & 1.41 & 0.12 & 386.59 & 29.74 \\
\hline & & $60-90$ & 1150.00 & 315.00 & 27.39 & 360.00 & 31.30 & 1.12 & 0.09 & 473.88 & 41.21 \\
\hline & & Mean & 2062.50 & 408.50 & & 458.00 & & 1.51 & & 1194.49 & \\
\hline \multirow{6}{*}{5} & \multirow{5}{*}{1500} & $0-15$ & 2750.00 & 464.00 & 16.87 & 390.00 & 14.18 & 1.75 & 0.06 & 1894.25 & 68.88 \\
\hline & & $15-30$ & 1835.00 & 425.00 & 23.16 & 440.00 & 23.97 & 1.45 & 0.08 & 968.55 & 52.78 \\
\hline & & $30-60$ & 970.00 & 370.00 & 38.14 & 470.00 & 48.45 & 1.32 & 0.14 & 128.68 & 13.27 \\
\hline & & $60-90$ & 688.00 & 308.00 & 44.77 & 325.00 & 47.24 & 0.95 & 0.14 & 54.05 & 7.86 \\
\hline & & Mean & 1560.75 & 391.75 & & 406.25 & & 1.37 & & 761.38 & \\
\hline & & $\begin{array}{l}\text { General } \\
\text { mean }\end{array}$ & 3661.65 & 389.85 & & .40 & & 1.48 & & 2830.92 & \\
\hline
\end{tabular}

* T-N: Total nitrogen, $\mathrm{NH}_{4}-\mathrm{N}$ : Ammonium nitrogen, $\mathrm{NO}_{3}-\mathrm{N}$ : Nitrate nitrogen, $\mathrm{NO}_{2}-\mathrm{N}$ : Nitrite nitrogen and $\mathrm{O}-\mathrm{N}$ : Organic nitrogen. 
Regarding the studied soil samples content of $\mathrm{NO}_{3}-\mathrm{N}$ as a percent of T-N which recorded in Table (4) may be noticed that, $\mathrm{NO}_{3}-\mathrm{N}$ represent the second fraction of T-N in the soil samples of Talkha area. In the studied area, the highest content of $\mathrm{NO}_{3}-\mathrm{N}$ as a percent of $\mathrm{T}-\mathrm{N}$ was found in the profile 1 , where the lowest one was recorded in profile 2 and increased with the distance increase from the factory. These results are in agreement with those obtained by Ju et al. (2006); Bordeleau et al. (2008); Graham et al. (2008); Zhao et al. (2011) and Garizabal et al. (2012).

Nitrite nitrogen $\left(\mathrm{NO}_{2}-\mathrm{N}\right)$.

The studied soil samples content $(\mathrm{mg} / \mathrm{kg})$ of $\mathrm{NO}_{2}-\mathrm{N}$ was very low, where its represent less than $2 \%$ of T-N as shown in Table (4). The content of $\mathrm{NO}_{2-}$ $\mathrm{N} \mathrm{mg} / \mathrm{kg}$ was decreased with the depth of soil increase, but its as a percent of T-N appeared no clear relation with soil depth. The vertical distribution of $\mathrm{NO}_{2}-\mathrm{N}$ in the studied area reveals that the main source of $\mathrm{NO}_{2}-\mathrm{N}$ in the soil of this area resulted from the outline products for the tested factory. So that the mean values of soil content of $\mathrm{NO}_{2}-\mathrm{N}$ in profile 1 was $1.02 \mathrm{mg} / \mathrm{kg}$ and its was $1.80 \mathrm{mg} / \mathrm{kg}$ in profile 2. The soil samples of Talkha area content of $\mathrm{NO}_{2}-\mathrm{N}$ was slight high.

\section{Organic nitrogen (O-N).}

The data in Table (4) show that O-N represent the main $\mathrm{N}$ forms in the studied area, where this content was decreased with the increase of soil depth. The high content of $\mathrm{O}-\mathrm{N}$ in the surface layer resulted from the high soil content (\%) of OM in this layer. Also, the highest content of O-N was found in profile 2, where the lowest one was found in profile 1. This may be due to the highest content of T-N found in the profile 2 while the lowest one was recorded in profile 1.

\section{Relationships Between Soil Properties and Its Content of Different Nitrogen Forms.}

The presented data in Table (5) show the correlation coefficients " $r$ " between the studied soil samples properties and the content of different $\mathrm{N}$ forms i.e. total- $\mathrm{N}, \mathrm{NH}_{4}-\mathrm{N}, \mathrm{NO}_{3}-\mathrm{N}, \mathrm{NO}_{2}-\mathrm{N}$, and $\mathrm{O}-\mathrm{N}$. The date show that the found values of " $r$ " appeared wide variations from property to another as well as from $\mathrm{N}$-forms to another. Concerning the correlation obtained for soluble cations, the data show higher values with $\mathrm{K}^{+}$and $\mathrm{Na}^{+}$and the lowest values were with $\mathrm{Mg}^{2+}$ and $\mathrm{Ca}^{2+}$ with

most $\mathrm{N}$-forms under study. In addition, the high values of " $r$ " were found with $\mathrm{Cl}^{-}$compared with other soluble anions. On the other hand, the soil samples of Talkha area content of $\mathrm{NO}_{3}-\mathrm{N}$ appeared affected by soil content of soluble cations and anions, where "r" values in the area were high.

Regarding the correlation between the studied soil chemical properties and its content of different $\mathrm{N}$-forms as presented in Table (5) may noted that the high "r" values were found with total- $\mathrm{N}$ and $\mathrm{NH}_{4}-\mathrm{N}$ and the lowest were found with $\mathrm{NO}_{3}-\mathrm{N}$ and $\mathrm{NO}_{2}-\mathrm{N}$. Except with soil pH and its content of $\mathrm{CaCO}_{3}$, all values of " $r$ " for different soil properties and $\mathrm{N}$-forms were positive. Most of 
soil chemical properties in Talkha area grade low values of " $r$ " with the determined $\mathrm{N}$ - forms.

Particle size distribution gave wide range for " $r$ " varied from negative to positive with different $\mathrm{N}$-forms (Table, 5). The soil contents of $\mathrm{T}-\mathrm{N}, \mathrm{NH}_{4}-\mathrm{N}$ and $\mathrm{OM}$ were positively correlated with different soil particle fractions, where the content of $\mathrm{NO}_{3}-\mathrm{N}$ and $\mathrm{NO}_{2}-\mathrm{N}$ were correlated negatively with the studied soil particle fractions. In general, all soil properties ( physical and chemical) have a greater and wide effects on the soil content of different $\mathrm{N}$-forms and its transformation from form to another.

Table (5): Correlation coefficient ( $r$ ) between the content of different $\mathrm{N}$ forms and some soil properties in the selected soil profiles located around Talkha fertilizer factory at Talkha at, Dakahlia Governorate.

\begin{tabular}{|c|c|c|c|c|c|c|}
\hline \multicolumn{2}{|c|}{ Soil properties } & T-N-Ns & $\mathrm{NH}_{4}-\mathrm{Ns}$ & $\mathrm{NO}_{3}-\mathrm{Ns}$ & $\mathrm{NO}_{2}-\mathrm{Ns}$ & ON-Ns \\
\hline \multirow{6}{*}{ Soluble cations } & $\mathrm{Na}^{+}$ & $\begin{array}{l}0.820 \\
0.000\end{array}$ & $\begin{array}{l}0.824 \\
0.000\end{array}$ & $\begin{array}{l}0.699 \\
0.000\end{array}$ & $\begin{array}{l}0.872 \\
0.000\end{array}$ & $\begin{array}{l}0.806 \\
0.000\end{array}$ \\
\hline & $\mathrm{K}^{+}$ & $\begin{array}{l}0.911 \\
0.000\end{array}$ & $\begin{array}{l}0.606 \\
0.001\end{array}$ & $\begin{array}{l}0.633 \\
0.001\end{array}$ & $\begin{array}{l}0.631 \\
0.001\end{array}$ & $\begin{array}{l}0.913 \\
0.000\end{array}$ \\
\hline & $\mathrm{Ca}^{+2}$ & 0.798 & 0.808 & 0.674 & 0.909 & 0.785 \\
\hline & $\mathrm{Ca}$ & 0.000 & 0.000 & 0.000 & 0.000 & 0.000 \\
\hline & & 0.564 & 0.458 & 0.671 & 0.520 & 0.552 \\
\hline & $\mathrm{Mg}^{2}$ & 0.003 & 0.021 & 0.000 & 0.008 & 0.004 \\
\hline \multirow{5}{*}{ Soluble anions } & $\mathrm{Cl}^{-}$ & 0.841 & 0.745 & 0.749 & 0.843 & 0.830 \\
\hline & & 0.781 & 0.098 & 0.000 & 0.000 & 0.000 \\
\hline & $\mathrm{HCO}_{3}^{-}$ & 0.000 & 0.000 & 0.000 & 0.000 & 0.000 \\
\hline & & 0.444 & 0.500 & 0.401 & 0.474 & 0.433 \\
\hline & $\mathrm{SO}_{4}$ & 0.026 & 0.011 & 0.047 & 0.017 & 0.030 \\
\hline \multirow{13}{*}{ Chemical properties } & & 0.865 & 0.823 & 0.769 & 0.883 & 0.852 \\
\hline & EC & 0.000 & 0.000 & 0.000 & 0.000 & 0.000 \\
\hline & $\mathrm{pH}$ & $\begin{array}{c}-0.791 \\
0.000\end{array}$ & $\begin{array}{l}-0.878 \\
0.000\end{array}$ & $\begin{array}{l}-0.616 \\
0.001\end{array}$ & $\begin{array}{c}-0.807 \\
0.000\end{array}$ & $\begin{array}{c}-0.776 \\
0.000\end{array}$ \\
\hline & OM & 0.722 & 0.854 & 0.689 & 0.915 & 0.702 \\
\hline & OIVI & 0.000 & .0000 & 0.000 & 0.000 & 0.000 \\
\hline & & -0.790 & -0.720 & -0.723 & -0.752 & -0.777 \\
\hline & $\mathrm{CaCO}_{3}$ & 0.000 & 0.000 & 0.000 & 0.000 & 0.000 \\
\hline & & 0.447 & 0.613 & 0.398 & 0.673 & 0.433 \\
\hline & CEC & 0.025 & 0.001 & 0.049 & 0.000 & 0.031 \\
\hline & & 0.581 & 0.836 & 0.697 & 0.749 & 0.556 \\
\hline & AP & 0.002 & 0.000 & 0.000 & 0.000 & 0.004 \\
\hline & & 0.771 & 0.778 & 0.720 & 0.887 & 0.757 \\
\hline & AK & 0.000 & 0.000 & 0.000 & 0.000 & 0.000 \\
\hline \multirow{10}{*}{$\begin{array}{l}\text { particle } \\
\text { distribution }\end{array}$} & Clav & 0.191 & 0.002 & -0.191 & 0.025 & 0.203 \\
\hline & Clay & 0.361 & 0.993 & 0.360 & 0.905 & 0.330 \\
\hline & Silt & 0.021 & 0.166 & -0.049 & 0.315 & 0.016 \\
\hline & Silt & 0.919 & 0.429 & 0.815 & 0.125 & 0.939 \\
\hline & Silt+Clay & 0.185 & 0.133 & -0.208 & 0.273 & 0.192 \\
\hline & Sili+clay & 0.375 & 0.525 & 0.319 & 0.187 & 0.358 \\
\hline & F-Sar & -0.135 & -0.076 & 0.243 & -0.228 & -0.143 \\
\hline & r-sar & 0.519 & 0.718 & 0.241 & 0.273 & 0.495 \\
\hline & C-Sand & -0.204 & -0.346 & -0.304 & -0.257 & -0.191 \\
\hline & c-sand & 0.327 & 0.091 & 0.140 & 0.215 & 0.359 \\
\hline
\end{tabular}


Regression equations and also regression coefficients " $R^{2 "}$ considered a best way to discusse and explain the relationships between soil properties and its content of different nutrients . Data in Table (6) show these relations between soil properties and its content of $\mathrm{N}$-forms. The found regression coefficient " $\mathrm{R}^{2 "}$ were varied widely for each $\mathrm{N}$-forms by the difference of soil properties. The found " $\mathrm{R}^{2 \mathrm{w}}$ values were high for all $\mathrm{N}$-forms.

Table (6): Regression equations and regression coefficients $\left(R^{2}\right)$ between the soil content of different $\mathrm{N}$-forms and some soil properties in the selected soil profiles located around Talkha fertilizer factory at Talkha at, Dakahlia Governorate.

\begin{tabular}{|c|c|c|}
\hline $\begin{array}{l}\text { Soil } \\
\text { properties }\end{array}$ & Regression equation & $\mathbf{R}^{2}$ \\
\hline \multirow{5}{*}{$\begin{array}{l}\text { Soluble } \\
\text { cations }\end{array}$} & $\mathrm{T}-\mathrm{N}-\mathrm{Ns}=-2983+49.1 \mathrm{Na}^{+}+3959 \mathrm{~K}^{+}+1083 \mathrm{Ca}^{+2}-230 \mathrm{Mg}^{+2}$ & 93.20 \\
\hline & $\mathrm{NH}_{4}-\mathrm{Ns}=106+7.42 \mathrm{Na}^{+}+19.2 \mathrm{~K}^{+}+43.3 \mathrm{Ca}^{+2}-4.1 \mathrm{Mg}^{+2}$ & 71.90 \\
\hline & $\mathrm{NO}_{3}-\mathrm{Ns}=256+9.60 \mathrm{Na}^{+}+10.90 \mathrm{~K}^{+}+17.20 \mathrm{Ca}^{+2}+25.00 \mathrm{mg}^{+2}$ & 65.00 \\
\hline & $\mathrm{NO}_{2}-\mathrm{Ns}=0.163+0.0179 \mathrm{Na}^{+}+0.0569 \mathrm{~K}^{+}+0.270 \mathrm{Ca}^{+2}-0.0207 \mathrm{Mg}^{+2}$ & 86.00 \\
\hline & $\mathrm{ON}-\mathrm{Ns}=-3350+31.70 \mathrm{Na}^{+}+3938 \mathrm{~K}^{+}+1058 \mathrm{Ca}^{+2}-252 \mathrm{Mg}^{+2}$ & 92.50 \\
\hline \multirow{5}{*}{$\begin{array}{l}\text { Soluble } \\
\text { anions }\end{array}$} & $\mathrm{T}-\mathrm{N}-\mathrm{Ns}=-6881+266 \mathrm{Cl}^{-1}+2172 \mathrm{HCO}^{-}+101 \mathrm{SO}^{-2}$ & 77.30 \\
\hline & $\mathrm{NH}_{4}-\mathrm{Ns}=-207+2.45 \mathrm{Cl}^{-1}+225 \mathrm{HCO}_{3}^{-}-2.78 \mathrm{SO}_{4}^{-2}$ & 82.70 \\
\hline & $\mathrm{NO}_{3}-\mathrm{Ns}=143+7.29 \mathrm{Cl}^{-1}+62.50 \mathrm{HCO}_{3}^{-}-2.86 \mathrm{SO}_{4}^{-2}$ & 61.60 \\
\hline & $\mathrm{NO}_{2}-\mathrm{Ns}=-0.671+0.0203 \mathrm{Cl}^{-1}+0.732 \mathrm{HCO}_{3}^{-}-0.0104 \mathrm{SO}_{4}^{-2}$ & 89.90 \\
\hline & $\mathrm{ON}-\mathrm{Ns}=-6790+257 \mathrm{Cl}^{-1}+1863 \mathrm{HCO}_{3}^{-}+103 \mathrm{SO}_{4}^{-2}$ & 74.40 \\
\hline \multirow{5}{*}{$\begin{array}{l}\text { Chemical } \\
\text { properties }\end{array}$} & $\begin{aligned} \mathrm{T}-\mathrm{N}-\mathrm{Ns}= & -48069+4151 \mathrm{EC}+5249 \mathrm{pH}+2676 \mathrm{OM}-1115 \mathrm{CaCO}_{3}+24 \mathrm{CEC}+ \\
& 24 \mathrm{AP}-2.71 \mathrm{AK}\end{aligned}$ & 84.20 \\
\hline & $\begin{array}{l}\mathrm{NH}_{4}-\mathrm{Ns}=1031-25.0 \mathrm{EC}-92 \mathrm{pH}+71.8 \mathrm{OM}-8.64 \mathrm{CaCO}_{3}-7.26 \mathrm{CEC}+54.2 \\
\text { AP }-0.0141 \mathrm{AK}\end{array}$ & 97.00 \\
\hline & $\begin{aligned} \mathrm{NO}_{3}-\mathrm{Ns}= & -372+45.5 \mathrm{EC}+31 \mathrm{pH}-76.0 \mathrm{OM}-4.8 \mathrm{CaCO}_{3}+3.18 \mathrm{CEC}+24.6 \\
& \mathrm{AP}+0.0872 \mathrm{AK}\end{aligned}$ & 81.20 \\
\hline & $\begin{aligned} \mathrm{NO}_{2}-\mathrm{Ns}= & -10.4+0.160 \mathrm{EC}+1.16 \mathrm{pH}+0.322 \mathrm{OM}-0.0291 \mathrm{CaCO}_{3}+0.00085 \\
& \mathrm{CEC}+0.129 \mathrm{AP}+0.000001 \mathrm{AK}\end{aligned}$ & 95.70 \\
\hline & $\begin{aligned} \mathrm{ON}-\mathrm{Ns}= & -49537+4138 \mathrm{EC}+5390 \mathrm{pH}+2655 \mathrm{OM}-1100 \mathrm{CaCO}_{3}+29 \\
& \mathrm{CEC}-53 \mathrm{AP}-2.77 \mathrm{AK}\end{aligned}$ & 82.60 \\
\hline \multirow{5}{*}{$\begin{array}{l}\text { Particle } \\
\text { size } \\
\text { distribution }\end{array}$} & $\mathrm{T}-\mathrm{N}-\mathrm{Ns}=-10784+140$ clay +108 clay + silt & 4.30 \\
\hline & $\mathrm{NH}_{4}-\mathrm{Ns}=41-5.8$ clay +7.92 clay + silt & 3.00 \\
\hline & $\mathrm{NO}_{3}-\mathrm{Ns}=943-3.49$ clay -4.57 clay + silt & 4.90 \\
\hline & $\mathrm{NO}_{2}-\mathrm{Ns}=-1.28-0.0397$ clay +0.0592 clay + silt & 11.40 \\
\hline & ON-Ns $=-11491+149$ clay +101 clay + silt & 4.80 \\
\hline \multirow{5}{*}{ General } & $\begin{aligned} \mathrm{T}-\mathrm{N}-\mathrm{Ns}= & -25860-1064 \mathrm{Na}^{+}+3891 \mathrm{~K}^{+}-903 \mathrm{Ca}^{+2}-1295 \mathrm{Mg}^{+2}+1084 \mathrm{Cl}^{-1} \\
& -2552 \mathrm{HCO}_{3}^{-1}+1273 \mathrm{SO}_{4}^{-2}-370 \mathrm{EC}+1171 \mathrm{pH}+1115 \mathrm{OM}-148 \\
& \mathrm{CaCO}_{3}+230 \mathrm{CEC}+397 \mathrm{AP}+0.38 \mathrm{AK}-78 \mathrm{Clay}+168 \text { clay+silt }\end{aligned}$ & 98.90 \\
\hline & $\begin{aligned} \mathrm{NH}_{4}-\mathrm{Ns}= & 1584+28.4 \mathrm{Na}^{+}-14.8 \mathrm{~K}^{+}+64.0 \mathrm{Ca}^{+2}+20.6 \mathrm{Mg}^{+2}-30.1 \mathrm{Cl}^{-1}+13.0 \\
& \mathrm{HCO}_{3}^{-1}-38.7 \mathrm{SO}_{4}^{-2}+43.4 \mathrm{EC}-133 \mathrm{pH}+43.9 \mathrm{OM}-19.6 \mathrm{CaCO}_{3}- \\
& 10.7 \mathrm{CEC}+38.3 \mathrm{AP}+0.024 \mathrm{AK}+3.31 \text { Clay }-4.08 \text { clay+silt }\end{aligned}$ & 98.40 \\
\hline & $\begin{aligned} \mathrm{NO}_{3}-\mathrm{Ns}= & -3113+0.1 \mathrm{Na}^{+}-22.2 \mathrm{~K}^{+}+42 \mathrm{Ca}^{+2}+19.7 \mathrm{Mg}^{+2}-1.5 \mathrm{Cl}^{-1}+62 \\
& \mathrm{HCO}_{3}^{-1}-6 \mathrm{SO}_{4}^{-2}-8 \mathrm{EC}+256 \mathrm{pH}-141 \mathrm{OM}+6.5 \mathrm{CaCO}_{3}+11.5 \\
& \mathrm{CEC}+24.0 \mathrm{AP}+0.145 \mathrm{AK}+10.0 \text { Clay }-3.7 \text { clay+silt }\end{aligned}$ & 89.60 \\
\hline & $\begin{aligned} \mathrm{NO}_{2}-\mathrm{Ns}=- & 8.40+0.0463 \mathrm{Na}^{+}-0.040 \mathrm{~K}^{+}+0.340 \mathrm{Ca}^{+2}+0.029 \mathrm{Mg}^{+2}- \\
& 0.0304 \mathrm{Cl}^{-1}+0.180 \mathrm{HCO}_{3}^{-1}-0.061 \mathrm{SO}_{4}^{-2}-0.093 \mathrm{EC}+1.14 \mathrm{pH} \\
& +0.216 \mathrm{OM}^{-0} 0.0490 \mathrm{CaCO}_{3}+0.0145 \mathrm{CEC}+0.0310 \mathrm{AP}+0.000318 \\
& \mathrm{AK}+0.0386 \text { clay }-0.0636 \text { clay+silt }\end{aligned}$ & 99.20 \\
\hline & $\begin{aligned} \mathrm{ON}-\mathrm{Ns}= & -24490-1081 \mathrm{Na}^{+}+3903 \mathrm{~K}^{+}-943 \mathrm{Ca}^{+2}-1334 \mathrm{Mg}^{+2}+1105 \mathrm{Cl}^{-1}- \\
& 2538 \mathrm{HCO}_{3}^{-1}+1300 \mathrm{SO}_{4}^{-2}-399 \mathrm{EC}+1139 \mathrm{pH}+1182 \mathrm{OM}-41 \\
& \mathrm{CaCO}_{3}+230 \mathrm{CEC}+308 \mathrm{AP}+0.28 \mathrm{AK}-82 \mathrm{clay}+159 \text { clay }+ \text { silt }\end{aligned}$ & 99.00 \\
\hline
\end{tabular}


These findings show a greater effect of all soil properties under study on the soil content of properties and its different $\mathrm{N}$ - forms. The clear observation which may be noted from the data in Table (6) is that, the lowest " $\mathrm{R}^{2 \text { " values }}$ for the different soil properties were found with $\mathrm{NO}_{3}-\mathrm{N}$. This means that the soil content of $\mathrm{NO}_{3}-\mathrm{N}$ have low affected by soil properties compared with those found with other $\mathrm{N}$-forms. In addition, these findings reveals that the soils content of $\mathrm{NO}_{3}-\mathrm{N}$ is high related with external factors i.e. fertilization, irrigation water, outline product of the presented industrial activities and others.

The presented data in Table (7) show the predicted soil content $(\mathrm{mg} / \mathrm{kg})$ of $\mathrm{NO}_{3}-\mathrm{N}$ using the regression equations listed in Table (6). Also, the content of predicted $\mathrm{NO}_{3}-\mathrm{N}\left(\mathrm{NO}_{3}-\mathrm{N}\right)$ as a percent of determined $\mathrm{NO}_{3}-\mathrm{N}(\mathrm{D}$ $\left.\mathrm{NO}_{3}-\mathrm{N}\right)$ in the same soil was calculated by $\left(\mathrm{NO}_{3}-\mathrm{N}\right) /\left(\mathrm{D} \mathrm{NO}_{3}-\mathrm{N}\right)^{*} 100$. These data show that more than $90 \%$ of the studied soil samples have $\mathrm{P}$ NO3-N more than $\mathrm{D} \mathrm{NO}_{3}-\mathrm{N}$.

These findings are clear in the soil profiles located after the studied nitrate source. Also, these findings become clear at the soil depth of $0-15$ and $15-30 \mathrm{~cm}$ compared with that at the depths of $30-60$ and $60-90 \mathrm{~cm}$. The lowest percent of $\mathrm{P} \mathrm{NO}_{3}-\mathrm{N}$ in the deeper soil layers in relation with different soil properties under study reveals and approved that the soilsof the studied area content of $\mathrm{NO}_{3}-\mathrm{N}$ was related with external factory such as fertilization, quality of irrigation water, pollution source...etc., more than those with soil properties. Regarding the calculated values of $\mathrm{P} \mathrm{NO}_{3}-\mathrm{N}$ as well it' a percent of $\mathrm{D} \mathrm{NO}{ }_{3}-\mathrm{N}$ may be also noted that the high values of $\mathrm{P} \mathrm{NO}_{3}-\mathrm{N}$ were found using the regression equation between soil chemical properties and the soil content of $\mathrm{NO}_{3}-\mathrm{N}$, except the soil profile located before the factory. On the other hand, the lowest percent was found using the regression equation of soluble anions(95.61)\%.

Irrigation and Drainage Water Chemical Composition.

The presented data in Table (8) show EC $\left(\mathrm{dSm}^{-1}\right)$ for both irrigation and drainage water in the studied area. In general, EC values were decreased with the distance increase from the factory compared with that in location 1.These findings reveals that, outline products of nitrogenous fertilizers resulted in an increase salinity level in both irrigation and drainage water. Irrigation water in Talkha area characterized by relative low EC values. On the other hand, drainage water in the same area have a high EC values. These results reveals that outline products reached to the soils and drains from fertilizers factory have a high content of soluble salts.

Regarding irrigation and drainage water $\mathrm{pH}$ presented in Table (8) may be noticed that, in both irrigation and drainage water in the studied area $\mathrm{pH}$ values were increased with the distance increase of the factory. At the same distance of the factory, $\mathrm{pH}$ was low in irrigation water than that in drainage water. These findings reveals that outline products of fertilizers factory have large amounts of acidic compounds. 
J. Soil Sci. and Agric. Eng., Mansoura Univ., Vol. 5 (5), May, 2014 
Regarding the content $(\mathrm{mg} / \mathrm{l})$ of $\mathrm{NH}_{4}-\mathrm{N}$ and $\mathrm{NO}_{3}-\mathrm{N}$ in both irrigation and drainage water, the data in Table (8) show that in both irrigation and drainage water at different distance of the factory, the water content of $\mathrm{NO}_{3}-\mathrm{N}$ was higher than that of $\mathrm{NH}_{4}-\mathrm{N}$. Also, at the same distance of the factory the content of $\mathrm{NH}_{4}-\mathrm{N}$ and $\mathrm{NO}_{3}-\mathrm{N}$ in drainage water was higher than found in irrigation water. These results are attributed to the large amounts of $\mathrm{NO}_{3}-\mathrm{N}$ reached directly from the final outline products of this factory to drainage water in addition with reached by leaching with irrigation water from different soil layers to drains.

Table (8):Some chemical analysis for both irrigation and drainage water taken at different distance of Talkha fertilizer factory at Talkha, Dakahlia Governorate.

\begin{tabular}{|c|c|c|c|c|c|c|c|c|c|}
\hline \multirow{2}{*}{ 坖 } & \multirow{2}{*}{ 丞 } & \multicolumn{4}{|c|}{ Irrigation water } & \multicolumn{4}{|c|}{ Drainage water } \\
\hline & & pH & $\begin{array}{c}\mathrm{EC}^{-1} \\
\left.(\mathrm{dSm})^{-1}\right)\end{array}$ & $\begin{array}{c}\mathrm{NH}_{4^{-}} \mathrm{N} \\
\mathrm{mg} / \mathrm{I}\end{array}$ & $\begin{array}{c}\mathrm{NO}_{3}-\mathrm{N} \\
\mathrm{mg} / \mathrm{I}\end{array}$ & Ph & $\begin{array}{c}E C \\
\left(\mathrm{dSm} m^{-1}\right)\end{array}$ & $\begin{array}{c}\mathrm{NH}_{4}-\mathrm{N} \\
\mathrm{mg} / \mathrm{I}\end{array}$ & $\begin{array}{c}\mathrm{NO}_{3}-\mathrm{N} \\
\mathrm{mg} / \mathrm{l}\end{array}$ \\
\hline 1 & -500 & 7.70 & 0.49 & 20.80 & 31.10 & 8.05 & 0.83 & 20.09 & 55.13 \\
\hline 2 & 000 & 7.50 & 0.99 & 28.70 & 38.50 & 7.75 & 1.98 & 92.40 & 130.20 \\
\hline 3 & 500 & 7.50 & 0.59 & 25.50 & 56.00 & 7.80 & 1.90 & 79.80 & 88.20 \\
\hline 4 & 1000 & 7.55 & 0.57 & 25.00 & 33.60 & 7.80 & 1.75 & 48.65 & 71.40 \\
\hline 5 & 1500 & 7.65 & 0.55 & 25.05 & 32.60 & 7.88 & 1.05 & 37.80 & 64.40 \\
\hline
\end{tabular}

\section{Plant Content of Nitrogen.}

The presented data in Table (9) show the content (\%) of $\mathrm{NH}_{4}-\mathrm{N}$ and $\mathrm{NO}_{3}$ $\mathrm{N}$ in both shoots and roots of plants cultivated in the studied area, at different distances of the factory. The content of both $\mathrm{NH}_{4}-\mathrm{N}$ and $\mathrm{NO}_{3}-\mathrm{N}$ in plant shoots was higher than that found in the plant roots. The content of $\mathrm{NO}_{3}-\mathrm{N}$ was higher than that found with $\mathrm{NH}_{4}-\mathrm{N}$. Also, the plant content of both $\mathrm{NH}_{4}-\mathrm{N}$ and $\mathrm{NO}_{3}-\mathrm{N}$ was decreased with the distance increase from factory. This trend was in harmony with the soil content of both $\mathrm{NH}_{4}-\mathrm{N}$ and $\mathrm{NO}_{3}-\mathrm{N}$ content in both soils and irrigation water. These results are in agreement with those obtained by Rahmani (2006); Tamme et al. (2006); Prasad and Avinesh (2008); Chen et al. (2010) and Huang et al. (2010).

Table (9): Plants content ( $\mathrm{mg} / \mathrm{kg}$ ) of different $\mathrm{N}$ - Forms at different distances of Talkha fertilizer factory of Talkha at of Dakahlia Governorate.

\begin{tabular}{|c|c|c|c|c|c|c|c|c|}
\hline \multirow{2}{*}{ 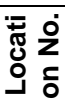 } & \multirow{2}{*}{ 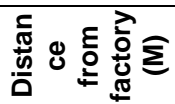 } & \multirow[b]{2}{*}{$\begin{array}{l}\text { Plant } \\
\text { type }\end{array}$} & \multicolumn{3}{|c|}{ Shoots } & \multicolumn{3}{|c|}{ Roots } \\
\hline & & & $\begin{array}{c}\mathbf{T}-\mathbf{N} \\
(\%)\end{array}$ & $\begin{array}{c}\mathrm{NH}_{4}-\mathrm{N} \\
(\%)\end{array}$ & $\begin{array}{c}\mathrm{NO}_{3}-\mathrm{N} \\
(\%)\end{array}$ & $\begin{array}{c}T-N \\
(\%)\end{array}$ & $\begin{array}{c}\mathrm{NH}_{4}-\mathrm{N} \\
(\%)\end{array}$ & $\begin{array}{c}\mathrm{NO}_{3}-\mathbf{N} \\
(\%)\end{array}$ \\
\hline 1 & -500 & Corn & 1.17 & 0.12 & 0.32 & 0.85 & 0.10 & 0.53 \\
\hline 2 & 000 & Rice & 1.50 & 0.17 & 0.71 & 1.25 & 0.17 & 0.71 \\
\hline 3 & 500 & Rice & 1.49 & 0.17 & 0.72 & 1.05 & 0.17 & 0.72 \\
\hline 4 & 1000 & Clover & 2.32 & 0.50 & 1.18 & 2.35 & 0.50 & 1.18 \\
\hline 5 & 1500 & Vridity & 2.44 & 0.67 & 1.51 & 2.12 & 0.67 & 1.51 \\
\hline
\end{tabular}


Thus it can be concluded that:-

1- The wastes of various industrial activities containing some hazard products.

So, such these products must be treated before dumping into the soil and water.

2- The products of the industrial activities must be analyzed.

3- The environment effects of industrial activities wastes must be evaluated according to environment protection law.

4- Designed program to prevent soil pollution.

5- Contentions evaluate to pollution status and development.

6- Account the needs of the crop of nitrogenous fertilizers.

7- Rationalization of the use of mineral fertilizers and raise its efficiency of use in agriculture.

8- The use of good agricultural practices

9- Management of irrigation water and agricultural drainage

10- Non-wasteful use as agricultural fertilizers

11- Not cultivate eny food crops specially that eating fresh in the polluted soil.

\section{REFERENCE:}

Al-Othman, Z. A; M. Naushad and Inamuddin (2011). Organic-inor- ganic Type composite cation exchanger poly-o-toluidine $\mathrm{Zr}$ (IV) tungstate: preparation, physicochemical characterization and its analytical application in separation of heavy metals. Chem. Engg.J., 172: 369 375.

Angelopoulos, K; I. C. Spiliopoulos; A. Mandoulaki; A. Theodorakopoulou and A. Kouvelas (2009). Groundwater nitrate pollution in northern part of Achaia Prefecture. Desalination., 248: 852 - 858.

APHA (1995). "Standard Methods for the Examination of Water and Wastewater Analysis," $19^{\text {th }}$ Ed.; American water works association, water environmental federation, Washington DC., 483 - 488.

Barrett, J. E. and I. C. Burke (2000). N immobilization in grassland soils: control by soil organic matter. Soil Biology and Biochemistry 32:17071716.Berrow, M. L. and G. A. Reaves (1984). Back Ground Levels of Trace elements

in Soils. International Conference, London.

Bertrand, I; D. Olivier and M. Bruno (2007). Carbon and nitrogen mineralization in acidic, limed and calcareous agricultural soils: Apparent and actual effects. Soil Biology \& Biochemistry., 39: 276 288.

Bordeleau,G;M.M.Savard; R.Martel and G.Ampleman (2008).Determination of the origin of groundwater nitrate at an air weapons range using the dual isotope approach. Journal of Contaminant Hydrology., 98 (3- 4), 97 - 105. 
Bremner, J. M and D. R. Keeney (1966). Determination and isotoperatio analysis of different forms of nitrogen in soils: 3 . Exchangeable ammonium, nitrate, and nitrite by extraction-distillation methods. Soil Science Society of American Journal., 30: 504 - 507.

Cemek, M; L. Akkaya; Y. O. Birdane; K. Seyrek; S. Bulut and K. Muhsin (2007). Nitrate and nitrite levels in fruity and natural mineral waters marketed in western Turkey. Journal of Food Composition and Analysis., 20: 236 - 240.

Chapman, H. D and P. F. Pratt (1961)."Methods of Analysis for Soils, Plants and Waters". Univ. of California, Dvi. Agric. Sc.

Chen, W. M; H. Liu and Q.M. Zhang (2010). Effect of nitrite on growth and microcystins production of Microcystis aeruginosa PCC7806. Journal of Applied Phycology. http://dx.doi.org/10.1007/s10811-0109558-y.

Cottenie, C. M; M. Verloo; L. Kikens; G. Velghe and R. Camerlynck. (1982). Analytical Problems and Methods in Chemical Plant and Soil Analysis". Hand book Ed. A. Cottenie, Gent, Belgium.

El-Melegy, H. A (2007). Effect of soil chemical and physical properties on Nitrogen forms and distribution in soils of Minufiya Governorate. M. Sc.Thesis. Faculty of Agric., Menufiya Univ., Shebin El-Kom, Egypt.

Eltilib, A. M; A. E. Elamin; M. M. El-Gaziri and Y. E. El mahi (2005).Combined effects of nitrogen fertilization and soil $\mathrm{CaCO}_{3}$ contents on corn performance in El-Marj soil, Libya. Journal of Plant Nutrition., 28:1619 - 1632.

Gami, S. K; J. G. Lauren and J. M. Duxbury (2009). Influence of soil texture and cultivation on carbon and nitrogen levels in soils of the eastern Indo- Gangetic Plains. Geoderma.,153: 304 - 311.

Garizabal,I.G; J. Causape and R. Abrahao (2012). Nitrate contamination and its relationship with flood irrigation management. Journal of Hydrology.,1-6. http://dx.doi.org/10.1016/j.jhydrol.2012.03.017

Graham, R. C; D. R. Hirmas; Y.A. Wood and C. Amrhein (2008). Large near- Surface nitrate pools in soils capped by desert pavement in the Mojave Desert ,California.Geology., 36, 3: 259 - 262.

Hongmei, B; W. Meng and Y. Zhang (2011). Nitrogen pollution and source identification in the Haicheng River basin in Northeast China. Science of the Total Environment., 409 : 3394 - 3402.

Huang, C; Z. Wang; S. Li and S. S. Malhi (2010). Nitrate in leaf petiole and blade spinach cultivars and its relation to biomass and water in plants. Journal of Plant Nutrition., 33: 1112 - 1123.

Jagessar, R. C. and O. Alleyne (2011).

Determination of nitrate anions concentrations in waste water from selected areas of coastal Guyana via a spectrophotometric method. International Journal of A cademic research., 3,1: 443 - 453. Part II. 
Ju, T; L. Kou; S. Zhang and P. Christie (2006). Nitrogen balance and groundwater nitrate contamination: comparison among three intensive cropping systems on the North China Plain. Environ. Pollut., $143:$ (1) $117-125$.

Katerji, N; J. W. Van Hoorn; A. Hamdy and M. Mastrorelli (2001). Salt Tolerance of crops according to three classifications methods and examination of some hypothesis about salt tolerance. Agric. Wat. Manage., 47: 1 - 8.

Kim, H. T. (1996)."Soil Sampling Preparation, and Analysis", Marcal Dekker, inc. New York . 391.

Mahvi, A. H; J. Nouri; A. Babaei and R. Nabizadeh (2005). Agricultural activities impact on groundwater nitrate pollution. Int. J. Environ. Sci. Technol., 2, 1: 41 - 47.

Nettleton, W. D. and F. F. Peterson (2010). Landform, Soil, and Plant Relationships to Nitrate Accumulation, Central Nevada. Geoderma GEODER- 10552; pp 6.

Page, A. L; R. H. Miller and D. R. Keeney (1982)." Methods of Soil Analysis" (ed.),Part 2, Am. Soc. Agron-Soil Sci. Sc. Am. Madison.Wis. USA. pp. $159-446$.

Prasad. S and A. Avinesh (2008). Nitrate-N determination in leafy vegetables. Study of the effects of cooking and freezing. Food Chem., 106: 772 - 780.

Rahmani, H. R (2006). Investigation of Nitrate pollution in the Soil,Water and Plants in Some gricultural Fields in Baraan (Esfahan). ENVIRONMENTAL SCIENCES.,11: 23 - 34.

Sapek, A (2005). Agricultural activities as a source of nitrates in ground water. Int Assoc Hydrogeol ., 5: 3 - 13.

Tamme, T; M. Reinik; M. Roasto; K. Juhkam; T. Tenno and A. Kiis (2006). Nitrates and nitrites in vegetables and vegetable - based products and their

intakes by the Estonian population. Food Addit Contam., 23: 355 - 361.

WHO (2004). Rolling Revision of the WHO Guidelines for Drinking Water Quality. Nitrates and Nitrites in Drinking Water, p. 133.

Yang, S; F. LI; D. UO; T. GUO; J. WANG; B. SONG and S. JIN (2006). Effect of Long-Term Fertilization on Soil Productivity and Nitrate Accumulation in Gansu Oasis. Agricultural Sciences in China., $5(1) 57-67$.

Zhao, B. Q; X. Y. Li; H. Liu; B. R. Wang; P. Zhu; S. M. Huang; D. J. Bao; Y. T. Li and H. B. So (2011). Results from long-term fertilizer experiments In China: Therisk of Groundwater pollution by nitrate. NJAS- Wageningen Journal of Life Sciences., 58: 177 - 183. 
تأثير مصنع الأسمدة النيتروجينية ( مصنع سماد طلخا) على حالة النترات فى البيئة الزراعية

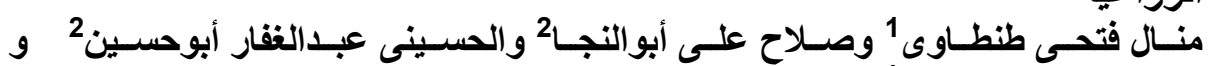
محمد سمير أبوالفتوح. 1

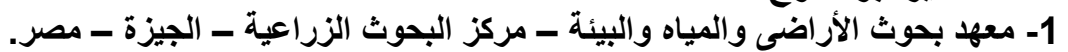
2- قسم علوم الأراضى - كلية الزراعلة - جامعة المنوفية ـ مصر.

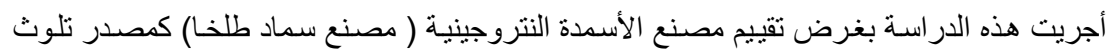

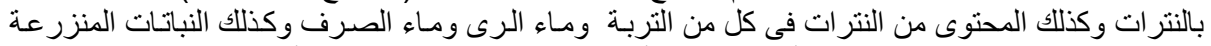

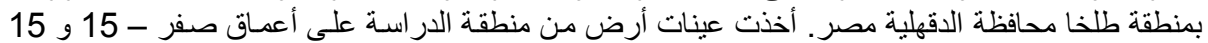

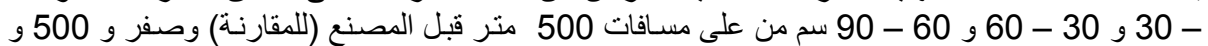

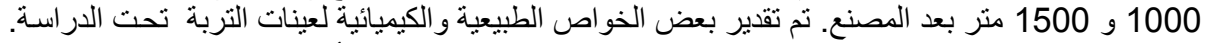

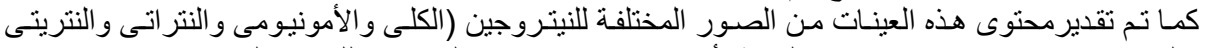

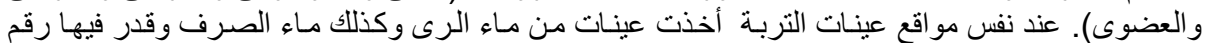

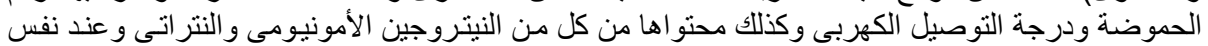

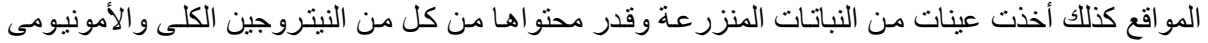

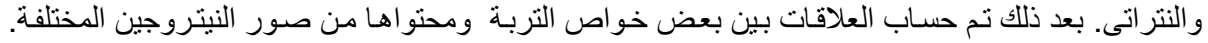

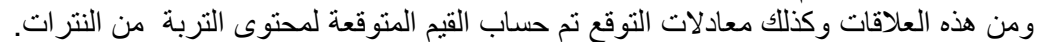

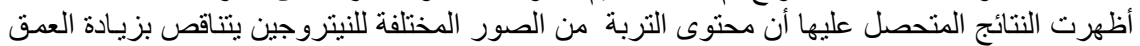

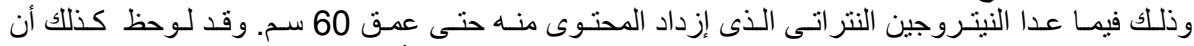

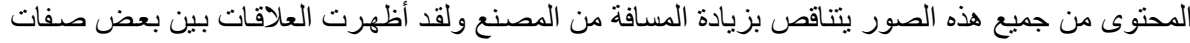

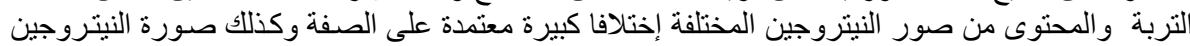

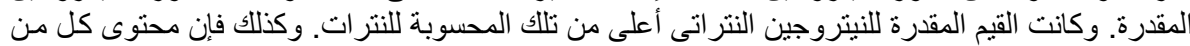

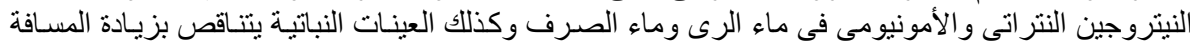

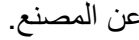


Table (7): Predicted Values of soil content $(\mathrm{mg} / \mathrm{kg})$ of nitrate $\left(\mathrm{P}-\mathrm{NO}_{3}{ }^{-}\right)$and it's a percent $(\%)$ of the determined nitrate $\left(\mathrm{D}-\mathrm{NO}_{3}{ }^{-}\right)$in relation with soil properties in the soil profile selected around Talkha fertilizer factory of Talkha, Dakahlia Governorate.

\begin{tabular}{|c|c|c|c|c|c|c|c|c|c|c|c|c|}
\hline \multirow{2}{*}{ 흔 } & \multirow{2}{*}{ 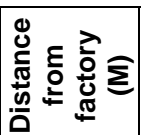 } & \multirow{2}{*}{$\begin{array}{l}\text { Soil } \\
\text { depth } \\
\text { (cm) }\end{array}$} & \multicolumn{2}{|c|}{$\begin{array}{l}\text { Soluble } \\
\text { cations }\end{array}$} & \multicolumn{2}{|c|}{$\begin{array}{l}\text { Soluble } \\
\text { anions }\end{array}$} & \multicolumn{2}{|c|}{$\begin{array}{l}\text { Chemical } \\
\text { properties }\end{array}$} & \multicolumn{2}{|c|}{$\begin{array}{l}\text { partical size } \\
\text { distribution }\end{array}$} & \multicolumn{2}{|c|}{ General } \\
\hline & & & $\begin{array}{c}\mathrm{P}^{-\mathrm{No}_{3}}{ }^{-} \\
(\mathrm{mg} / \mathrm{kg})\end{array}$ & $\begin{array}{c}\% \text { of } \\
\text { D-No }{ }_{3}^{-}\end{array}$ & $\begin{array}{c}\mathrm{P}^{-\mathrm{No}_{3}^{-}} \\
(\mathrm{mg} / \mathrm{kg})\end{array}$ & $\begin{array}{c}\text { \%of } \\
\text { D-No } \\
-\end{array}$ & $\begin{array}{c}\mathrm{P}^{-\mathrm{No}_{3}^{-}} \\
(\mathrm{mg} / \mathrm{kg})\end{array}$ & $\begin{array}{c}\% \text { of } \\
\text { D- } \mathrm{No}_{3}^{-}\end{array}$ & $\begin{array}{c}\mathrm{P}^{-\mathrm{No}_{3}}{ }^{-} \\
(\mathrm{mg} / \mathrm{kg})\end{array}$ & $\begin{array}{c}\% \text { of } \\
\mathrm{D}-\mathrm{No}_{3}-\end{array}$ & $\begin{array}{c}\mathrm{P}^{-\mathrm{No}_{3}} \\
(\mathrm{mg} / \mathrm{kg})\end{array}$ & $\begin{array}{c}\% \text { of } \\
\mathrm{D}-\mathrm{No}_{3}\end{array}$ \\
\hline \multirow{5}{*}{1} & \multirow{5}{*}{-500} & $0-15$ & 534.70 & 187.61 & 403.30 & 141.51 & 331.12 & 116.18 & 390.44 & 136.99 & 334.63 & 117.42 \\
\hline & & $15-30$ & 486.75 & 131.56 & 356.90 & 96.46 & 319.08 & 86.24 & 430.15 & 116.26 & 334.59 & 90.43 \\
\hline & & $30-60$ & 452.81 & 117.61 & 330.76 & 85.91 & 328.91 & 85.43 & 446.78 & 116.05 & 343.11 & 89.12 \\
\hline & & $60-90$ & 426.48 & 174.07 & 303.90 & 124.04 & 294.13 & 120.04 & 434.13 & 177.19 & 305.14 & 124.55 \\
\hline & & Mean & 475.27 & & 349.05 & & 317.51 & & 425.37 & & 329.67 & \\
\hline \multirow{5}{*}{2} & \multirow{5}{*}{0} & $0-15$ & 751.22 & 148.76 & 496.79 & 98.37 & 552.59 & 109.42 & 407.85 & 80.76 & 501.44 & 99.29 \\
\hline & & $15-30$ & 815.34 & 137.03 & 580.22 & 97.52 & 509.73 & 85.67 & 418.36 & 70.31 & 599.44 & 100.75 \\
\hline & & $30-60$ & 755.41 & 128.04 & 444.32 & 75.31 & 563.73 & 95.55 & 461.62 & 78.24 & 579.36 & 98.19 \\
\hline & & $60-90$ & 543.19 & 132.49 & 385.52 & 94.03 & 467.64 & 114.06 & 482.22 & 117.61 & 439.25 & 107.13 \\
\hline & & Mean & 716.36 & & 476.88 & & 532.22 & & 442.69 & & 531.78 & \\
\hline \multirow{5}{*}{3} & \multirow{5}{*}{500} & $0-15$ & 682.69 & 142.82 & 501.93 & 105.01 & 481.08 & 100.64 & 428.31 & 89.60 & 500.98 & 104.81 \\
\hline & & $15-30$ & 633.67 & 121.63 & 466.65 & 89.57 & 500.42 & 96.05 & 438.54 & 84.17 & 505.14 & 96.96 \\
\hline & & $30-60$ & 585.42 & 106.05 & 454.93 & 82.41 & 514.28 & 93.17 & 441.44 & 79.97 & 518.02 & 93.84 \\
\hline & & $60-90$ & 587.61 & 148.76 & 420.49 & 106.46 & 468.61 & 118.64 & 433.71 & 109.80 & 447.32 & 113.25 \\
\hline & & Mean & 622.51 & & 460.89 & & 488.34 & & 437.99 & & 502.66 & \\
\hline \multirow{5}{*}{4} & \multirow{5}{*}{1000} & $0-15$ & 640.25 & 139.19 & 497.57 & 108.17 & 463.33 & 100.73 & 435.75 & 94.73 & 447.64 & 97.31 \\
\hline & & $15-30$ & 585.66 & 119.04 & 427.04 & 86.79 & 523.80 & 106.46 & 471.41 & 95.81 & 554.38 & 112.77 \\
\hline & & $30-60$ & 569.60 & 109.54 & 399.18 & 76.77 & 482.99 & 92.88 & 458.36 & 88.15 & 523.78 & 100.73 \\
\hline & & $60-90$ & 491.92 & 136.64 & 375.17 & 104.22 & 387.07 & 107.52 & 463.20 & 128.67 & 379.19 & 105.33 \\
\hline & & Mean & 571.83 & & 424.87 & & 470.44 & & 457.19 & & 471.57 & \\
\hline \multirow{6}{*}{5} & \multirow{5}{*}{1500} & $0-15$ & 572.58 & 146.82 & 395.55 & 101.42 & 383.06 & 98.22 & 413.33 & 105.98 & 401.14 & 102.86 \\
\hline & & $15-30$ & 487.96 & 110.90 & 387.94 & 88.17 & 418.45 & 95.10 & 434.59 & 98.77 & 425.57 & 96.72 \\
\hline & & $30-60$ & 491.82 & 104.64 & 364.81 & 77.62 & 416.85 & 88.69 & 447.28 & 95.17 & 437.28 & 93.04 \\
\hline & & $60-90$ & 459.5 & 141.39 & 331.06 & 101.87 & 327.09 & 100.64 & 446.77 & 137.47 & 302.82 & 93.17 \\
\hline & & Mean & 503.17 & & 369.85 & & 389.20 & & 435.46 & & 402.33 & \\
\hline & & $\begin{array}{c}\text { General } \\
\text { mean }\end{array}$ & 577.83 & & 416.31 & & 439.54 & & 439.74 & & 447.60 & \\
\hline
\end{tabular}


Tantawy, Manal F. et al. 